\title{
Image analysis: a new method for estimating triploidy in commercial bivalves
}

\author{
A. GERARD, Y. NACIRI, J.-M. PEIGNON, C. LEDU, \\ P. PHELIPOT, C. NOIRET, I. PEUDENIER \& H. GRIZEL \\ IFREMER, Unité de Recherche en Génétique et Ecloserie, La Tremblade, France
}

\begin{abstract}
For determination of ploidy levels in bivalves, three techniques are now routinely used: karyological determination, microfluorimetry and flow cytometry. This paper proposes an alternative technique which is based on determination of the optical density (OD) of stained nuclei using image analysis. A karyological and image analysis comparative exper iment conducted on juveniles of Crassostrea gigas (Thunberg) and Ruditapes philippinarum (Adam \& Reeve) is described and highlights the advantages of the image analysis technique. Initially developed on $C$. gigas and $R$. philippinarum, the image analysis method was easily cxtended to other bivalve species and to different developmental stages, as demonstrated by two experiments conducted on Ostrea edulis (L.). First, percentage of triploids was consistent from the D-larval to the adult stage of development, despite the use of different preparation techniques depending on the stage examined. Second, a rise in ploidy percentage demonstrated a differential mortality between diploid and triploid animais. Image analysis techniques arc cheaper than flow cytometry but more expensive than microfluorimetry. However, image analysis equipment can also be used for algac, eggs and spermatozoa counting. and other purposes such as fluorescence measurements, analysis of autoradiographs and electrophoresis gels, and measurement of immuno-histochemical reactions.
\end{abstract}

\section{Introduction}

In aquaculture, the production of triploid animals has now proved to be of interest to farmers. Numerous studies on fish and shellfish have demonstrated the link between triploidization and sterility (Chourrout \& Quillet 1982; Allen, Downing, Chaiton \& Beattie 1986; Allen \& Downing 1990). As a consequence of sterility, some reallocation in energetic flow appears to occur. For molluscs, such reallocations are not only advantageous for growth, but also for glycogen levels in storage tissues. In triploids, glycogen levels remain higher and more stable during the reproductive period than in diploid animals (Allen \& Downing 1986). During this period, triploid molluses consequently increase their resistance to stress and also have an improved meat quality (Allen \& Downing 1991).

Different triploidization methods are now well known, such as heat shocks (Quillet \& Panelay 1986; Yamamoto \& Sugawara 1988; Yamamoto et al. 1988, 1990), pressure shocks (Chaiton \& Allen 1985; Allen et al. 1986), cytochalasin B treatments (Allen \& Downing 1986, 1990; Downing 1989) and, more recently, 6-DMAP treatments (Desrosiers, Gérard, Peignon, Naciri, Dufresne, Morasse, Ledu, Phélipot, Guerrier \& Dubé 1992).

Correspondence: Dr A. Gérard, IFREMER, Unité de Recherche en Génétique ct Ecloserie, BP 133, Ronce les Bains, 17390 La Tremblade, France. 
All of these methods have been successfully applied to several mollusc species, particularly commercial ones: Crassostrea gigas (Thunberg) (Allen et al. 1986; Downing \& Allen 1987), C. virginica (Gmelin) (Stanley, Allen \& Hidu 1981; Allen 1987), Ruditapes philippinarum (Adams \& Reeve) (Diter \& Dufy 1990; Dufy \& Diter 1990), Chiamys nobilis (Thurnberg) (Komaru, Uchimura, Ieyama \& Wada 1988), Mytilus edulis (L.) (Yamamoto \& Sugawara 1988; Beaumont \& Kelly 1989; Yamamoto et al. 1990), and many Pectinidae species (Beaumont \& Fairbrother 1991 for review). In the USA, some of the above techniques are routinely used in hatcheries, and triploid spat represented half of the production for the west coast in 1991 (Allen, personal communication). Unfortunately, all previous methods to date have failed to produce $100 \%$ triploid samples and, therefore, it is still necessary for hatcheries to have a method for percentage triploidy determination in spat. The triploid percentage also varies during early development, from fertilization to juvenile stages. In order to check the ploidy level at every stage of mollusc life, it is essential to develop a simple and reproducible technique. Amongst the present techniques used, three are likely to fill this need: karyology as described by Thiriot-Quiévreux \& Ayraud (1982), flow cytometry as described by Chaiton \& Allen (1985), and DNA microfluorimetry as recommended by Komaru et al. (1988) and Uchimura, Komaru, Wada, Ieyama, Yamaki \& Furuta (1989). In this paper we propose numerical imagery as a fourth alternative method. This technique, routinely used in medical check-ups to determine the ploidy level of cancerous cells (Giroud 1987), has been applied in our laboratory to different species of molluscs, at different stages of development.

\section{Materials and methods}

\section{Biological material and triploidy inductions}

Triploidy was induced using the methods of Downing \& Allen (1987) and Desrosiers et al. (1993) for C. gigas, the method of Dufy \& Diter (1990) for $R$. philippinarum and the method of Gendreau \& Grizel (1988) modified after Gérard (unpublished data) for $O$. edulis. Ploidy levels in $C$. gigas and $R$. philippinarum were determined both by karyological and image analysis methods. Ploidy levels in $O$. edulis were determined only by image analysis.

\section{Preparation of spat for karyological analysis}

Live juveniles of $C$. gigas and $R$. philippinarum $(10$ to $20 \mathrm{~mm})$ were incubated for $12 \mathrm{~h}$ with $0.005 \%$ colchicine in filtered sea water. Animals were then killed, the gills dissected out and treated for $30 \mathrm{~min}$ in $0.9 \%$ sodium citrate in distilled water. Procedures are similar to those described by Thiriot-Quiévreux \& Ayraud (1982). Tissues were fixed in freshly prepared Carnoys solution (absolute alcohol and acetic acid, 3:1) with three consecutive washes each of $20 \mathrm{~min}$ duration. Cells were then dissociated for $10 \mathrm{~min}$ in $50 \%$ solution of acetic acid. Suspended cells were dropped onto slides previously heated to $45^{\circ} \mathrm{C}$. Each slide preparation was made from one single individual. Slides were then stained with $4 \%$ Giemsa ( $\mathrm{pH} 6.8$ ) for $10 \mathrm{~min}$. Slides were viewed with an Olympus BH2 microscope and photographs obtained using an Olympus camera. 


\section{Image analysis equipment}

The image analysis equipment consists principally of a microscope and a computer, both linked to a camera. A program called Samba ${ }^{\mathrm{TM}} 2005$ and developed by Alcatel-France controls the whole system. The program analyses the photometric intensity of stained nuclei and gives their individual integrated optical density (IOD). DNA indices (DI) are computed for these individual IOD values by comparison with a mean IOD derived from a diploid control. Expected values of DI will be 1.0 for a diploid sample, 1.5 for a triploid, and 2 for a tetraploid.

Samba ${ }^{\mathrm{TM}} 2005$ is built on three subprograms: Ploidy, Stat 2005 and Samba. Ploidy centralizes all the functions which analyse the DNA content of cells and which reorder the data from the different samples and controls. Stat 2005 computes statistical analyses from the cellular parameters recorded through Ploidy. It also gives graphic representations. Samba accommodates black-and-white or colour images.

\section{Preparation of samples for image analysis}

It was possible to carry out image analysis on single adult individuals, and on spat which exceeded $5 \mathrm{~mm}$ in size. For embryos, larvae, and postlarvae $(<5 \mathrm{~mm})$, analyses were carried out on cell populations only.

Embryos. One important characteristic of embryos is their high mitotic activity. Quantification of the embryo DNA content must therefore be assayed during the G1 division stage, when the chromosome number is $2 \mathrm{~N}$. Fixing the cells at this stage is also essential when a cell population derived from different individuals with different ploidy levels is studied. For this purpose, two mitotic inhibitors were tested for cell preparation. These were hydroxyurea, which inhibits protein synthesis and consequently DNA replication, and aphidicolin, which inhibits DNA synthesis through DNA polymerases. These two chemicals were tested with 4-h-old swimming embryos. Embryos were immersed in the different solutions for a period of $2 \mathrm{~h}$. For this experiment, two controls were used. The first used an untreated sample, from which we expected to obtain a population of $2 \mathrm{~N}$ cells. The other used a colchicine-treated sample. This chemical is known to disorganize the achromatic system and we then expected to obtain a mixed population of $2 \mathrm{~N}$ cells and cells in the process of division (i.e. with $4 \mathrm{~N}$ chromosomes).

After the mitotic inhibitor treatment, larvae were removed, and left for decantation with a drop of $37 \%$ formol solution. A hypotonic shock was then applied over a $20 \mathrm{~min}$ period in a mixture of fresh water and sea water (3:1). The water was then removed by centrifugation $\left(5 \mathrm{~min}, 1000 \mathrm{rpm}, 8^{\circ} \mathrm{C}\right)$. The sample was immersed three times in Carnoys solution with a 5 min centrifugation after each immersion. After the last immersion, the Carnoys solution was removed and embryos were soaked for $10 \mathrm{~min}$ in $200 \mu \mathrm{l}$ of a $50 \%$ acetic acid solution. Cell dissociation was helped by gentle stirring. Drops of this solution were then transferred onto a $45^{\circ} \mathrm{C}$ heated slide.

Larvae and postlarvae. For larvae and postlarvae up to $5 \mathrm{~mm}$, analysis of a cell population coming from a pool of individuals was also necessary. Several thousand larvae were left fasting for a whole night. Five millilitres of swimming larvae were removed to which a drop of $50 \%$ formol solution was added. The poured-off larvae were taken after decantation and the sample was crushed with a Dounce agitator in 10 times its own 
volume of citric acid ( $7 \%$ in filtered sea water). This was repeated six times. The resulting cell suspension was taken off and centrifuged for $10 \mathrm{~min}$ at $1000 \mathrm{rpm}$ at $8^{\circ} \mathrm{C}$. The supernatant was removed and the cell deposit resuspended in $1 \mathrm{ml}$ of $7 \%$ citric acid. Centrifugation was repeated once more before dropping the deposit onto a slide.

Small spat. For small spat (from 5 to $20 \mathrm{~mm}$ ), it was not possible to perform biopsies successfully so whole animals had to be killed. Each shell was opened under a microscope, and the viscera removed where possible. The remaining flesh was used to obtain a smear by touching it gently onto a slide.

Spat and adults. For spat (larger than $20 \mathrm{~mm}$ ) and adults, a preparation technique was developed which allowed us to keep the animals alive. Shells were cleaned before making a small aperture in each of them. The animals were then immersed in a solution of magnesium chloride ( $70 \mathrm{~g} / \mathrm{l}$ in filtered sea water, Hervio 1992). Magnesium chloride is known to anaesthetize oysters without lasting effects when animals are re-immersed in sea water. After a period of $15 \mathrm{~min}$ to $4 \mathrm{~h}$, the shells usually gaped in such a way that it was possible to take a small piece of the gills. This piece of the gills was then touched onto a slide in order to obtain their print without crushing the tissue. The slides were then airdried. For the special purpose of comparing karyology and image analysis, animals were treated with colchicine as described above, killed, and gill prints were taken after the treatment.

Fixation and staining. Embryo slides were fixed with Carnoys solution for $10 \mathrm{~min}$. For larvae, postlarvae, spat and adults, fixation was obtained by immersion of slides in a Bohm Sprenger solution for $10 \mathrm{~min}$. All slides were stained following the standard FeulgenRosalin method.

\section{Ploidy level determination}

Following Ahmed \& Spark (1967) and Gérard (1978), chromosome number was assumed to be 20 for the oysters $C$. gigas and $O$. edulis, and 38 for the clam, $R$. philippinarum. For karyotypic analysis, an individual was designated triploid when its chromosome number was 30 for oysters and 57 for clams. For image analysis, when spat or adults were studied, the average integrated optical density (IOD) of each individual was computed from a minimum of 50 cells and then compared with the IOD value of a diploid control, in order to obtain the DNA index. For samples pooled from different individuals, as was the case for embryonic and larval preparations, a minimum of 200 cells were analysed. Statistical treatments, based on IOD gaussian decompositions, allowed us to obtain the triploid versus diploid cell percentages.

\section{Results}

Comparison of individual ploidy levels using karyological and image analysis

Two comparisons were carried out, one with 24 juveniles of Ruditapes philippinatrum and the other with 20 juveniles of Crassostrea gigas (Table 1). For both species, animal sizes varied between 20 and $50 \mathrm{~mm}$. Both samples were treated with cytochalasin $B$ to induce triploidy. 
Table 1. Comparison between karyological analysis and image analysis for determining ploidy level for spat of elams and oysters. For image analysis, the mean inicgrated optical density (IOD), the IOD standard deviation (SD) and the DNA index compared with a diploid control is given for each spat. For karyological analysis, cach individual is characterized by jts chromosome number (chrom. no.)

\begin{tabular}{|c|c|c|c|c|c|c|c|c|c|c|}
\hline \multicolumn{5}{|c|}{ Ruditapes philippinarum } & & \multicolumn{5}{|c|}{ Crassostrea gigas } \\
\hline \multicolumn{3}{|c|}{ Image analysis } & \multirow{2}{*}{$\frac{\text { Karyology }}{\text { Chrom. no. }}$} & \multirow{2}{*}{$\begin{array}{l}\text { Ploidy } \\
\text { lcvel }\end{array}$} & \multirow[b]{2}{*}{ Spat } & \multicolumn{3}{|c|}{ Image analysis } & \multirow{2}{*}{$\frac{\text { Karyology }}{\text { Chrom. no. }}$} & \multirow{2}{*}{$\begin{array}{c}\text { Ploidy } \\
\text { level }\end{array}$} \\
\hline Mcan IOD & IOD SD & DNA index & & & & Mean IOD & IOD SD & DNA index & & \\
\hline 36256 & 4627 & $1 \cdot 644$ & 57 & $3 N$ & 1 & 16049 & 6810 & $1 \cdot 545$ & 30 & $3 \mathrm{~N}$ \\
\hline 22950 & 3309 & $1 \cdot 041$ & - & $2 \mathrm{~N}$ & 2 & 9190 & 1619 & 0.885 & 20 & $2 \mathrm{~N}$ \\
\hline 35061 & 1146 & $1 \cdot 590$ & - & $3 \mathrm{~N}$ & 3 & 14428 & 1707 & $1 \cdot 389$ & 30 & $3 N$ \\
\hline 30504 & 4893 & 1.383 & 57 & $3 \mathrm{~N}$ & 4 & 9677 & 1538 & 0.032 & 20 & $2 \mathrm{~N}$ \\
\hline 20179 & 4881 & 0.915 & 38 & $2 N$ & 5 & 9710 & 2150 & 0.935 & 20 & $2 N$ \\
\hline 34248 & 9580 & $1 \cdot 553$ & 57 & $3 \mathrm{~N}$ & 6 & 15728 & 4006 & $1 \cdot 514$ & 30 & $3 N$ \\
\hline 30892 & 7863 & 1.401 & 57 & $3 N$ & 7 & 8863 & 1962 & 0.853 & 20 & $2 \mathrm{~N}$ \\
\hline 32353 & 4171 & 1.467 & 57 & $3 N$ & 8 & 15512 & 1865 & $1 \cdot 493$ & 30 & $3 N$ \\
\hline 34013 & 3771 & $1 \cdot 542$ & - & $3 N$ & 9 & 9460 & 536 & 0.911 & 20 & $2 N$ \\
\hline 34676 & 4946 & 1.572 & - & $3 \mathrm{~N}$ & 10 & 11057 & 3560 & 1.065 & 20 & $2 N$ \\
\hline 33693 & 2149 & 1.528 & - & $3 N$ & 11 & 10774 & 1591 & 1.037 & 20 & $2 \mathrm{~N}$ \\
\hline 24300 & 827 & $1 \cdot 102$ & 38 & $2 \mathrm{~N}$ & 12 & 10387 & 2089 & 1.000 & 20 & $2 N$ \\
\hline 32268 & 3278 & 1.463 & 57 & $3 N$ & 13 & 14842 & 2581 & $1 \cdot 429$ & 30 & $3 N$ \\
\hline 19432 & 1299 & 0.881 & 38 & $2 \mathrm{~N}$ & 14 & 17015 & 3626 & 1.638 & 30 & $3 N$ \\
\hline 33820 & 10882 & $1 \cdot 533$ & 57 & $3 N$ & 15 & 10898 & 1440 & $1 \cdot 049$ & 20 & $2 \mathrm{~N}$ \\
\hline 20993 & 410 & 0.952 & 38 & $2 N$ & 16 & 16324 & 3702 & $1 \cdot 572$ & 30 & $3 N$ \\
\hline 31357 & 5.560 & $1 \cdot 422$ & - & $3 \mathrm{~N}$ & 17 & 15560 & 3640 & 1.498 & 30 & $3 N$ \\
\hline 32336 & 7984 & $1 \cdot 466$ & - & $3 \mathrm{~N}$ & 18 & 16779 & 3426 & 1.615 & 30 & $3 N$ \\
\hline 34616 & 6311 & 1.569 & 57 & $3 N$ & 19 & 9877 & 2385 & 0.951 & 20 & $2 N$ \\
\hline 33200 & 1438 & $1 \cdot 505$ & - & $3 N$ & 20 & 1.0505 & 3952 & $1 \cdot 011$ & 20 & $2 \mathrm{~N}$ \\
\hline 38342 & 10362 & 1.738 & - & $3 N$ & 21 & & & & & \\
\hline 21785 & 2119 & 0.988 & 38 & $2 \mathrm{~N}$ & 22 & & & & & \\
\hline 25475 & 3999 & $1 \cdot 155$ & - & $2 \mathrm{~N}$ & 23 & & & & & \\
\hline 24995 & 4464 & $1 \cdot 133$ & 38 & $2 \mathrm{~N}$ & 24 & & & & & \\
\hline
\end{tabular}


For $C$. gigas the ploidy levels obtained by the two techniques are identical, both methods indicating that 9 out of 20 juveniles were triploid. DNA indices varied from 0.853 to 1.065 for diploids and from 1.389 to 1.638 for tripoids. The average IOD coefficient of variation (IOD standard deviation divided by IOD mean) over all individuals is slightly higher for triploids (22\%) than for diploids $(21 \%)$.

For $R$. philippinarum, comparisons were only possible for 14 of the 24 juveniles. There was good agreement in ploidy levels estimated by the two techniques. For the 10 remaining individuals, it was not possible to classify them using the karyological method due to difficulties in counting chromosome numbers. On the other hand, the ploidy level was clearly established by image analysis for all individuals. DNA indices varied from 0.881 to 1.155 for diploids and from 1.383 to 1.738 for triploids. As with C. gigas, the average IOD coefficient of variation is higher for triploids $(17 \%)$ than for diploids $(12 \%)$.

For both $C$. gigas and $R$. philippinarum, high levels of variation were obtained in IOD values, producing DNA indices differing slightly from the theoretical values of 1.0 and 1.5 for diploids and triploids respectively. Such variations can be explained by the use of colchicine. Colchicine is known to block at metaphase those cells that are in the process of dividing. The samples analysed were consequently made up of cells with $2 \mathrm{~N}$ and cells with $4 \mathrm{~N}$ chromosomes. Such a situation affected the analysis and explains the high variation in the IOD levels obtained. Later treatments did not use colchicine and as illustrated in Fig. 1 show that dividing cells are usually very rare, as can be expected for juveniles and adults. In the two experiments shown in Fig. 1, conducted on 22 juveniles of both $C$. gigas and $R$. philippinarum, variation in IOD levels was substantially less. For $C$. gigas, the average IOD variation coefficients were equal to $10 \%$ for diploids and $14 \%$ for triploids (compared with $21 \%$ and $22 \%$ in the experiment using colchicine); for $R$. philippinarum, the average variation coefficients were 3\% for both diploids and triploids (instead of $12 \%$ and $17 \%$ respectively). For routine analysis, a sample was then assumed to be diploid if its DNA index lay between 0.9 and 1.1 , and triploid if its DNA index lay between 1.4 and 1.6 .

\section{Enhancement of embryo sample preparations for image analysis}

Results obtained from the different mitotic inhibitor treatments are shown in Fig. 2. For the untreated sample, the population DNA level is highly heterogeneous with a single diploid $2 \mathrm{C}$ peak corresponding to those cells which are not in the process of dividing. With colchicine treatment an expected second tetraploid $4 \mathrm{C}$ peak appears. When comparing the hydroxyurea and aphidicolin treatments, it appears that the latter gives better results, yielding a homogeneous concentration of cells around the $2 \mathrm{C}$ level. Results from a further experiment, conducted with different concentrations of hydroxyurea and aphidicolin. confirmed this first conclusion (data not shown) and further demonstrated that hydroxyurea treatment was never as good as aphidicolin treatment, even when high concentrations were used. Furthermore, it appears that increasing the aphidicolin concentration used produces no improvement in results. Taking into account the high price of aphidicolin, a concentration of $5 \mu \mathrm{g} / \mathrm{ml}$ was used in subsequent experiments. One of these experiments, conducted on pediveliger larvae coming from a cytochalasin B-treated spawn of C. gigas is illustrated in Fig. 3. Two peaks, the first one of $2 \mathrm{C}$ cells and the second of $3 \mathrm{C}$ cells, are clearly identified. The gaussian decomposition gives more information on the respective 


\section{Cytochalasin $\theta$ treated sample}

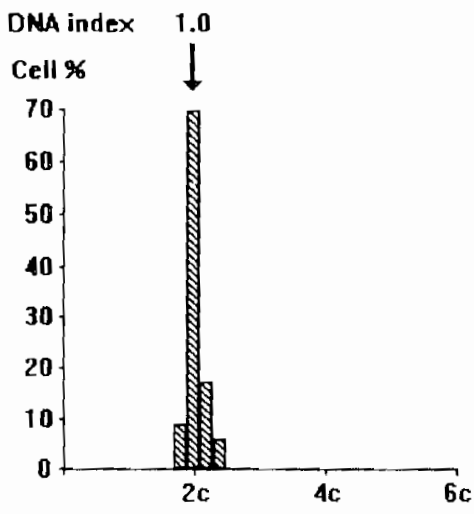

Cylochalasin 8 treated sample

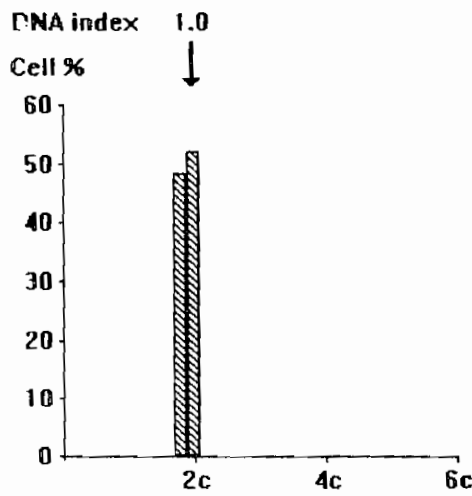

Cytochalasin $\theta$ treated sample

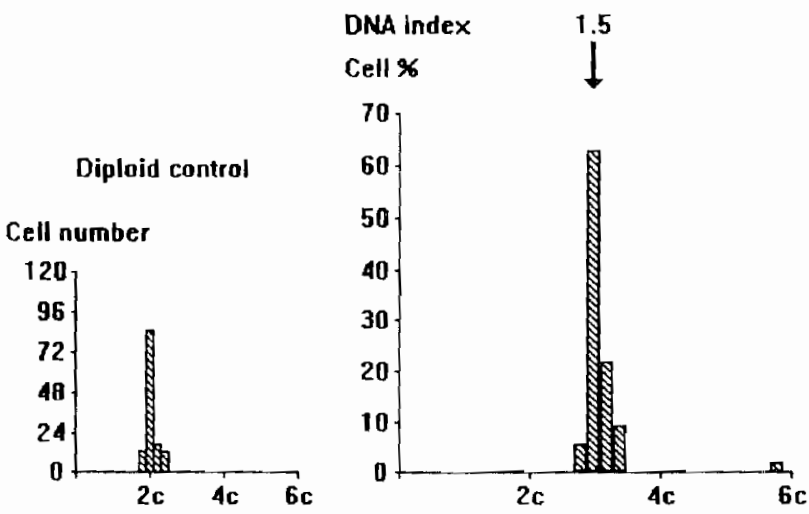

\section{Crassostrea gigas}

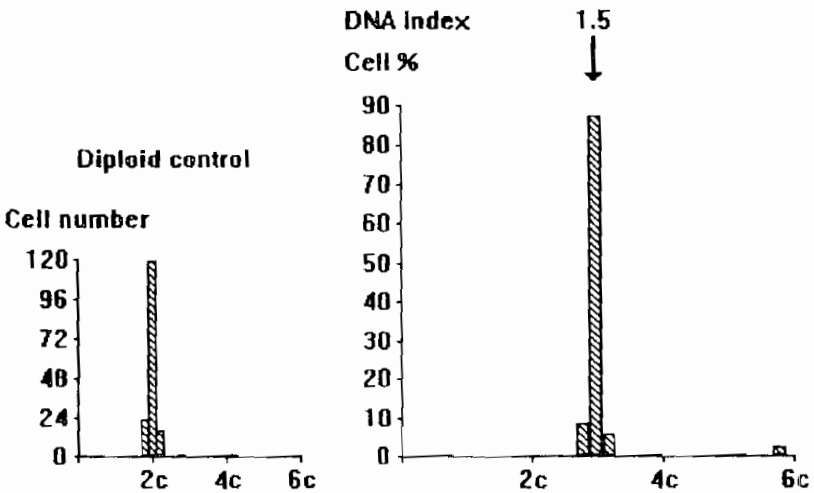

\section{Ruditapes philippinarum}

Figure 1. Ploidy distributions obtained by routine analysis for spat of Crassostrea gigas and Ruditapes philippinarum. Diploid and triploid individuals of a given species come from the same $1 \mathrm{mg}$ CB-treated batch.

proportions of diploid and triploid cells in the population studied. The analysed sample was composed of 32 cells from diploid embryos and 154 cells from triploid embryos. At this stage of development, it can then be assumed with an $\alpha=5 \%$ probability, that $83 \%$ of the total larval population was composed of triploid embryos (Fig. 4).

\section{A study of triploid samples of Ostrea edulis}

Ploidy determination using image analysis was applied to Ostrea edulis. The purpose of 


\section{Untreated sample}

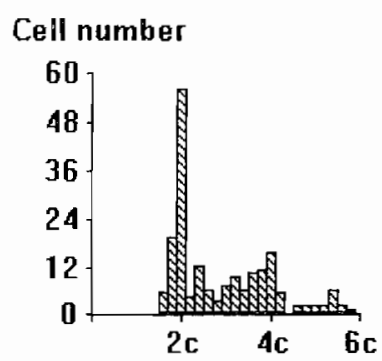

Hydroxyurea $500 \mu \mathrm{g} / \mathrm{ml}$

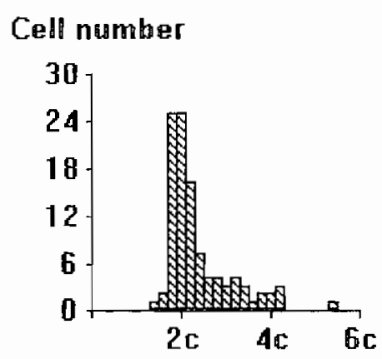

Colchicine $0,2 \mathrm{~g} / \mathrm{l}$

Cell number

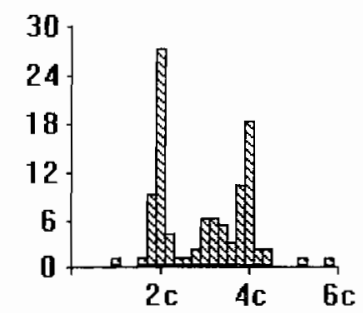

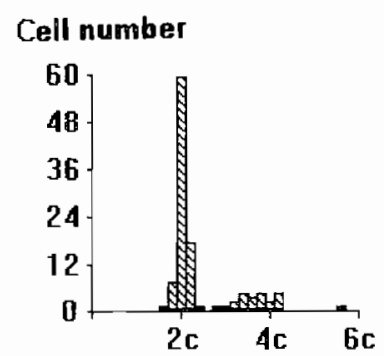

Figure 2. Distribution of ploidy level within cell populations taken from 4-hour-old diploid embryos of Crassostrea gigas previously trcated with different mitotic inhibitors.

\section{Cytochalasin B treated sample}

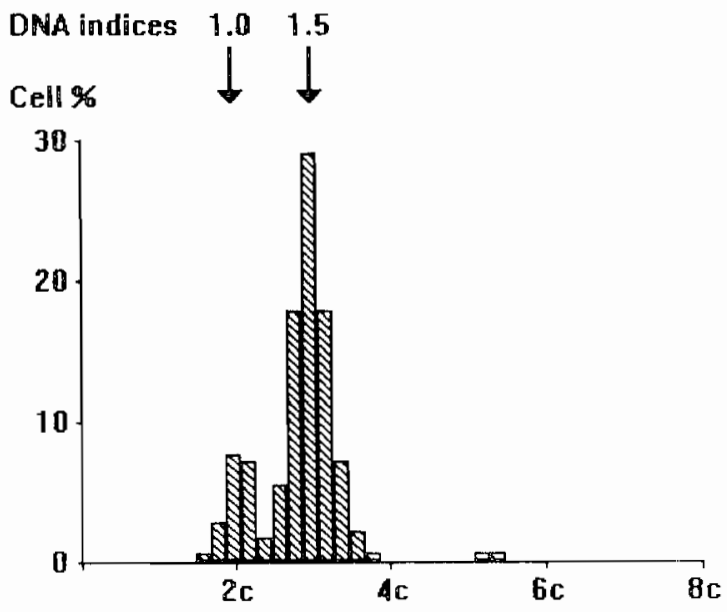

Figure 3. Distribution of the ploidy level within a cell population obtained from pediveliger larvae of Crassostred argas previously treated with cytochalasin B. compared with a diploid control population. 


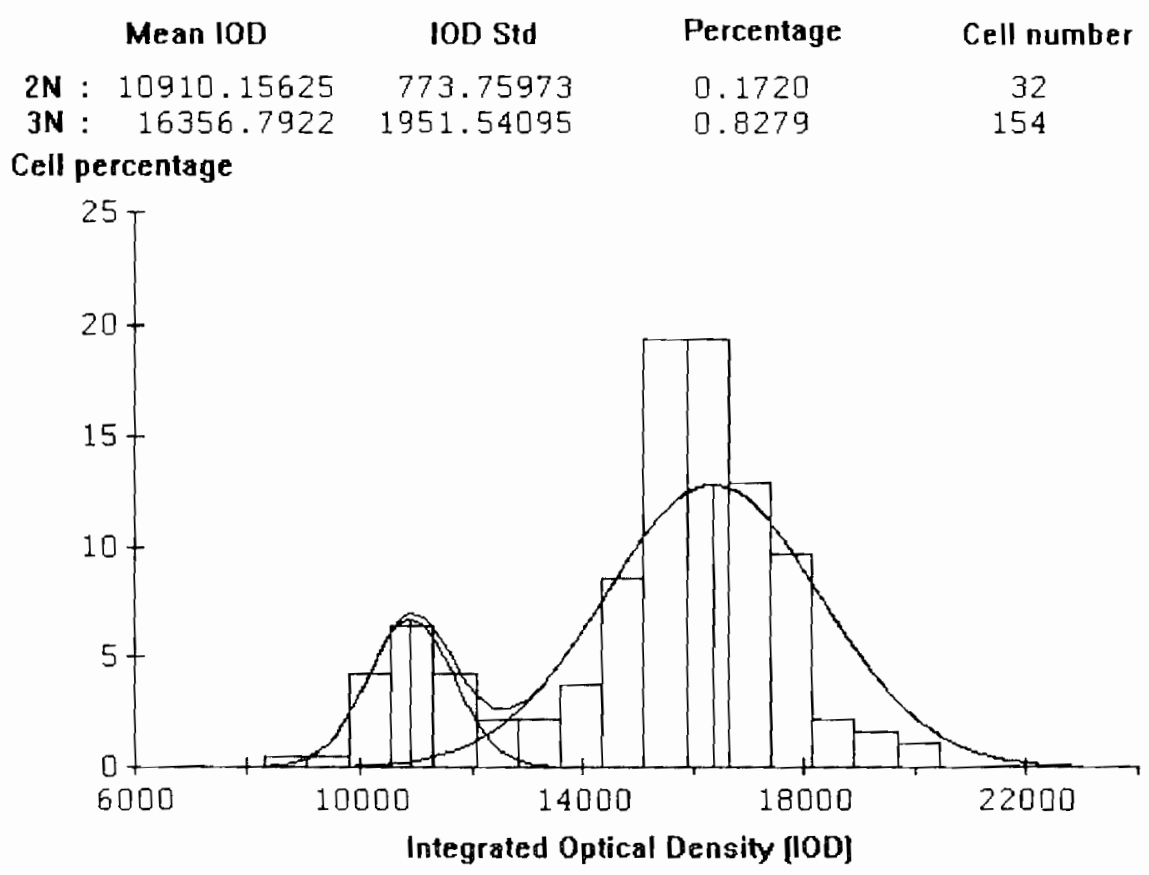

Figure 4. Gaussian distribution of integrated optical density values (IOD) for a cell population from pediveliger larvac of Crassostrea gigas previously treated with cytochalasin B.

the study was to follow, in two cytochalasin B-treated populations, the change in percentage triploidy over a number of developmental stages. Ploidy levels were obtained for Dshaped larvae, pediveliger larvae, postlarvae and spat. Figure 5 illustrates that one of the samples possessed a high percentage of triploids and this remained stable $(80-90 \%)$ from the D-larval to the juvenile stage of development. However, in the second sample, the triploidy percentage was initially lower $(31 \%)$ in D-larvae, but rose to $70 \%$ by the juvenile stage, presumably because of differential mortality. In spite of the use of different preparation techniques for larvae, postlarvae and spat, our results indicate that it is possible to monitor the ploidy level of any treated population.

\section{Discussion}

This article reports how a very efficient method used in human medicine for determining the ploidy level of cancerous cells (Giroud 1987) has been adapted for estimating ploidy levels in marine bivalve species. Moreover, this article proposes a method for use with embryos, larvae, juvenile and adult preparations which, when combined with image analysis, permits determination of the ploidy ratio of every sample at the earliest stage possible. This method gives an answer to the problem raised by Chaiton \& Allen (1985) and Uchimura et al. (1989) concerning the difficulty of having enough cells at G1 stage to permit ploidy determination in embryos. Mitotic inhibition with aphidicolin allows us to obtain a clear gaussian decomposition of the cell population into diploid and triploid subpopulations. For older animals, in which cells divide more slowly than in embryos, 


\section{Ostrea edulis}

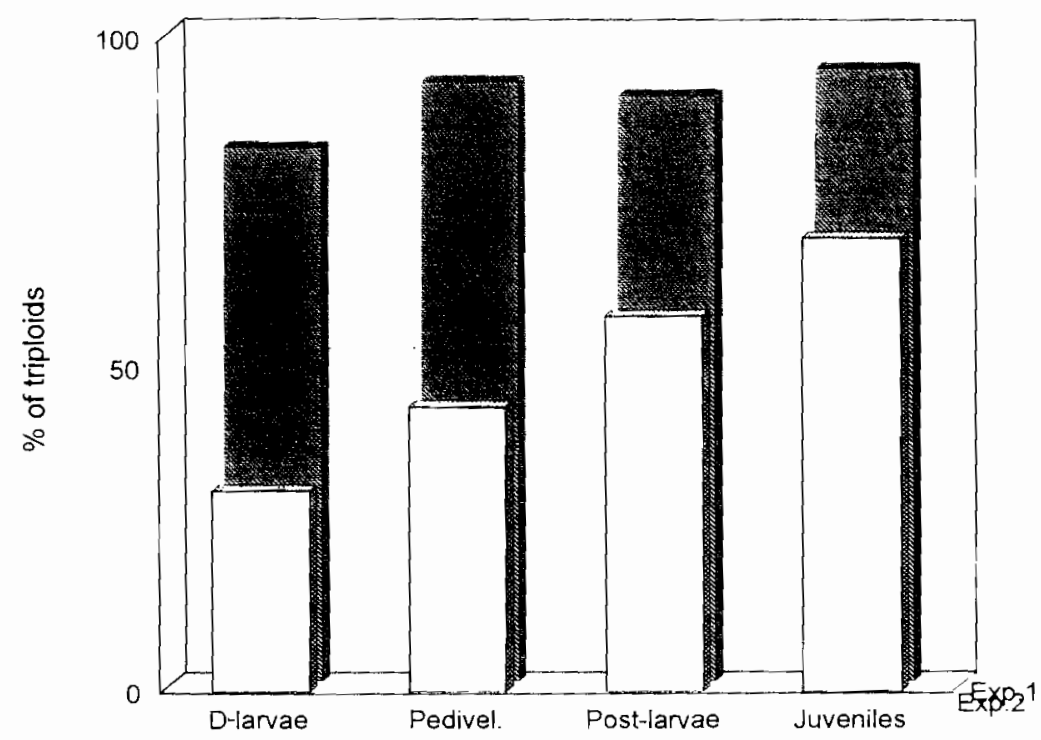

Figure 5. Change in percentage triploidy from D-shaped larval stage to juvenile slage in two cytochalasin B-treated populations of Ostrea edulis.

image analysis is easier to carry out than karyological analysis. Furthermore, this new method can be applied very easily to different bivalve species. Initiated with $C$. gigas and $R$. philippinarum, the image analysis technique has been successfully extended to $O$. edulis and $R$. decussatus (unpublished data). Image analysis presents one disadvantage, however, as it does not give any information on chromosome structure, as karyotyping does. This can be a limitation in cases where experiments include treatments, such as pressure shocks, which are known to damage the chromosomes. We must also underline that the success of ploidy determination is tightly linked to homogeneous slide staining.

Compared with other methods, namely microfluorimetry with DAPI staining (Komaru et al. 1988), and flow cytometry (Chaiton \& Allen 1985), image analysis can be employed at different stages of the bivalve life cycle, and either for cell populations or for individuals. This technique is cheaper than flow cytometry but more expensive than microfluorimetry. However, the same inage analysis ecinipment can also be used in hatcheries for purposes such as identification and counting of phytoplankton species, counting of eggs and spermatozoa, fluorescence measurements, and autoradiograph and electrophoretic analyses.

In conclusion, image analysis appears to be a very efficient method for ploidy determination, especially for scientists who conduct experiments which need regular monitoring from the earliest larval stages to the spat, as well as for hatcheries which need to determine the tripioid ratio of the populations they sell or buy. 


\section{Acknowledgments}

We thank the regional Councii of Poitou-Charentes region for providing funding for this work. We also thank Dr P. Shaw and the two anonymous referees for their helpful comments on the manuscript.

\section{References}

Ahmed M. \& Spark A.K. (1967) A preliminary study of chromosomes of two species of oysters (Ostrea hurida and Crassostrea gigas). Joumal of the Fisheries Research Board of Canada 24(10), 2155-2159.

Allen S.K. Jr (1987) Flow cytometry: assaying experimental polyploid fish and shellfish. Aquaculture 33 , $317-328$.

Allen S.K. Jr \& Downing S.L. (1986) Performance of triploid Pacific oysters. Crassostrea gigas (Thunberg). 1. Survival, growth, glyeogen content, and sexua! maturation in yearlings. Journal of Experimental Marine Biology and Ecology 102, 197-208.

Alten S.K. Jr \& Downing S.L. (1990) Performance of triploid Pacific oysters Crassostrea gigas: Gametogenesis. Canadian Journal of Fisheries and Aquatic Sciences 47, 1213-1222.

Allen S.K. Jr \& Downing S.L. (1991) Consumers and "experts" alike prefer the taste of sterile triploid over gravid diploid Pacific oysters (Crassostrea gigas. Thunberg, 1793). Joumal of Shellfish Research 10(1), $19-22$.

A!len S.K. Jr, Downing S.L., Chaiton J. \& Beattie J.H (1986) Chemically and pressure-induced triploidy in the Pacific oyster Crassostrea gizas. Aquaculture 57, 359-360.

Bcaumont A.R. \& Fairbrother J.E. (1991) Ploidy manipulation in molluscan shellfish: a rcview. Joumal of Shellfish Research 10(1), 1-18.

Bcaumont A.R. \& Kclly K.S. (1989) Production and growth of triploid Myrilus edulis larvae. Journal of Experimental Marine Biology and Ecology 132, 69-84.

Chaiton J. \& Allen S.K. (1985) Early detection of triploidy in the larvac of Pacific oysters Crassostrea gigas by flow cytometry. Aquaculture 48, 35-43.

Chourrout D. \& Quillet E. (1982) Induced gynogenesis in the rambow trout: sex and survival of progenies. Production of all-triploid populations. Theoretical and Applied Genetics 63, 201-205.

Desrosiers R.R., Gérard A., Peignon J.-M., Naciri Y.. Dufresne L., Morassc J., Ledu C., Phelipot P., Guerrier P. \& Dubć F. (1993) A novel method to produce triploid embryos in bivalve molluses by the use of 6-dimethylaminopurine. Joumal of Experimental Marine Biology and Ecology 170, 29-43.

Diter A. \& Dufy C. (1990) Polyploidy in the Manila clam, Ruditapes philippinartun. II. Chemical induction of tetraploid cmbryos. Aquatic Living Resources 3, 107-112.

Downing S.L. (1989) Escimating polyploid percentages using oyster larvae: a valuable hatchery management and rescarch tool Journal of Shelltish Research 8(1), 320. (Abstract only.)

Downing S.L. \& Alien S.K. Jr (1987) Induced triploidy in the Paeific oyster Crassostrea gigas: optimal treatments with Cytochalasin B depend on temperature. Aquaculture 61, 1-15.

Dufy C. \& Diter A. (1990) Polyploidy in the Manila clam, Ruditapes philippinartim. 1. Chemical inducton and larvac performances of triploids. Aquatic Living Resources 3, 55-60.

Gendreau S. \& Grizel H. (1.88) Induced trip!nidy and tetraploidy in the European flat oyster Ostrea eduits (L.). Aquaculture 90, 229-238.

Gerard A. (1978) Etude des garnitures chromosomiques de deux Veneridae: Ruditapes decussatus (L.) et Ruditapes philippinarum (Adams et Reeve). Haliotis 9(1), 69-71.

Giroud F. (1987) Approches cytométriques de la prolifération è de la différenciation: notion de faciès cleromatuien. Thèsc de l'Université Scicntifique. Technologique et Medicale de Grenoblc. $243 \mathrm{pp}$.

Hervio D. (1992) Contribution à létude de Bonamia ostrea (Ascetospora), protozoaire paraste de l'hutre Ostrca edulis (Bivahia) et à l'analve des interactions hôte-parasite. These de I'Universite Blaise Pascal de Clermont-Fcrand. $170 \mathrm{pp}$.

Komaru A.. Uchimura Y., Icyama H. \& Wada K.T (1988) Detection of induecd triploid scallop Chamy. nobilis by DNA microfitorometry with DAPI staining. Aquaculture 69, 201-209.

Qullet E. \& Panclay P.J. (1986) Triploidy induction by thermal shocks in the Japanese oyster Crassostrea gigas Acucaculture 57, $271-274$ 


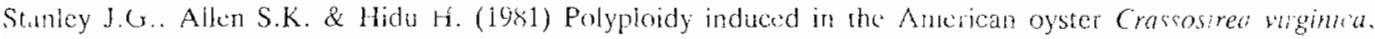
with cylochalasin B. Aquaculute 12, 1- 10 .

Thiriot-Quiévreux C. \& Ayraud N. (1982) Les caryotypes de quelques espèces de Bivalves et de Gastéropode: marins. Marine Biology 70, 165-172.

Uchimura Y., Konaru A.. Wada K.T., leyama H., Yamaki M. \& Furuta H. (1989) Detection of induced triploidy at difierent ages for larvac of the Japanese pearl oyster. Pinctada fucata martensii, by microfluoro. metry with DAPI staining. Aquaculture 76, $1-9$.

Yandinuto S. \& Sugawara Y. (1988) Induced triploidy in the inussel Mytilus eduls. by temperature shock. Aquaculture 72, 21-29.

Yamamow S., Sugawara Y., Nomura T. \& Oshino A (1988) Induced tripleiviy in Pacifie oycter Cressostrees gigas. and performance of triploid larvae. Tohoku Joumal of Agriculural Research 39, 47-59.

Yamamow S. Sugawara Y. \& Nomura ' $T$ (1990) Chemical and thermal control of triploid production in Pacific oystcrs and mussels, with regard to controlling meiotic maturation. In: Advances in invertebrate Reproduction 5

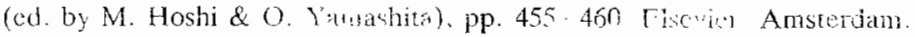

